ERRATUM

Martin Gajewski - Manuel Girschick · Dirk Sieger

\title{
Comparative analysis of her genes during fish somitogenesis suggests a mouse/chick-like mode of oscillation in medaka
}

Published online: 6 April 2006

(C) Springer-Verlag 2006

\section{Dev Genes Evol (2006): DOI 10.1007/s00427-006-0059-6}

Martin Gajewski, Manuel Girschick and Dirk Sieger are affiliated to:

Universität zu Köln, Institut für Genetik, Zülpicher Str. 47, 50674 Köln,

Germany

The affiliation had been omitted in the original publication.

The online vesion of the original article can be found at http://dx. doi.org/10.1007/s00427-006-0059-6.

M. Gajewski $(\bowtie) \cdot$ M. Girschick · D. Sieger

Universität zu Köln,

Institut für Genetik,

Zülpicher Str. 47,

50674 Köln, Germany

e-mail: martin.gajewski@uni-koeln.de 